\title{
Anti-Cyclic Citrullinated Peptide Antibodies in Rheumatoid Arthritis and Their Relationship with Extra-Articular Manifestations
}

\author{
Romatoid Artritte Anti-Siklik Sitrulinli Peptid Antikorlar ve \\ Bunların Ekstra-Artiküler Bulgular ile İlişkisi
}

\author{
Özgür ORTANCIL, ${ }^{1}$ Nercivan BULMUŞ, ${ }^{1}$ Şenay ÖZDOLAP, ${ }^{1}$ Sibel KIRAN, ${ }^{2}$ Mehmet ARASLI ${ }^{3}$ \\ ${ }^{1}$ Department of Physical Medicine and Rehabilitation, Medical Faculty of Zonguldak Karaelmas University, Zonguldak, Turkey; \\ ${ }^{2}$ Department of Public Health, Medical Faculty of Zonguldak Karaelmas University, Zonguldak, Turkey; \\ ${ }^{3}$ Department of Immunology, Medical Faculty of Zonguldak Karaelmas University, Zonguldak, Turkey
}

Objectives: In this study, we investigated the relationship
between extra-articular manifestations (EAM) and anti-cyclic
citrullinated peptide (anti-CCP) antibodies.

Patients and methods: Sixty-seven patients (53 females, 14 males; mean age $57.4 \pm 13.5$ years; range 26 to 82 years) diagnosed with rheumatoid arthritis (RA) according to the ACR (American College of Rheumatology) criteria between January 2009 December 2009 were included in the study. The age, gender, disease duration, and EAMs (rheumatoid nodules, pulmonary nodules, pulmonary fibrosis, keratoconjunctivitis sicca) of each patient were recorded, and the anti-CCP antibody and rheumatoid factor (RF) positivity and serum RF levels were evaluated.

Results: Extra-articular manifestations were present in $28(41.8 \%)$ of the patients. Anti-CCP antibodies were present in $34(50.7 \%)$ patients. Positivity of anti-CCP antibodies was found in $16(57.1 \%)$ patients with EAM compared to $18(46.2 \%)$ patients without EAM ( $p>0.05)$. Rheumatoid factor positivity was found in $23(82.1 \%)$ patients with EAM compared with $30(76.9 \%)$ patients without EAM ( $p>0.05)$. The serum levels of RF were 176.5 \pm 201.7 $\mathrm{IU} / \mathrm{ml}$ in the patients with EAM, and $114.1 \pm 144.8 \mathrm{IU} / \mathrm{ml}$ in the patients without EAM ( $p>0.05)$. The mean serum titers of RF were significantly higher in the patients with pulmonary fibrosis than in those without pulmonary fibrosis $(237.8 \pm 204.8 \mathrm{IU} / \mathrm{ml}$ and $118.9 \pm 158.6 \mathrm{lU} / \mathrm{ml}$ respectively; $p=0.036$ ).

Conclusion: It is known that EAMs increase morbidity and mortality in patients with rheumatoid arthritis. Thus, the markers that help identify patients with severe disease have an important role in making a decision for early aggressive treatment. Studies that investigate the relationship between anti-CCP antibodies and EAM have conflicting results. In this study, no relationship was found between the antibodies against citrullinated peptides and the presence of EAMs. We think that further studies with a larger sample size are necessary to evaluate the relationship between EAM and anti-CCP antibodies.

Key words: Anti-CCP antibodies; extra-articular involvement; rheumatoid arthritis; rheumatoid factor.
Amaç: $\mathrm{Bu}$ çalışmada anti-siklik sitrulinli peptid (anti-CCP) antikorlar ile ekstra-artiküler tutulum (EAT) arasındaki ilişki araştırıldı.

Hastalar ve yöntemler: Çalışmaya Ocak 2009 - Aralık 2009 tarihleri arasında ACR (American College of Rheumatology) tanı kriterlerine göre romatoid artrit (RA) tanısı konulan 67 hasta (53 kadın, 14 erkek; ort. yaş 57.4+13.5 yıl; dağılım 26-82 yı) dahil edildi. Tüm hastaların yaşları, cinsiyetleri, hastalık süreleri ve EAT'leri (romatoid nodül, pulmoner nodül, pulmoner fibroz, keratokonjonktivitis sikka) kaydedildi ve romatoid faktör (RF) ve anti-CCP antikor pozitifliği ve serum RF seviyeleri değerlendirildi.

Bulgular: Hastaların 28'inde (\%41.8) EAT saptandı. Otuz dört hastada (\%50.7) anti CCP antikorlar mevcuttu. AntiCCP antikor pozitifliği EAT'li 16 hastada (\%57.1) saptanırken, EAT'si bulunmayan 18 hastada (\%46.2) saptandı ( $p>0.05)$. Romatoid faktör pozitifliği EAT'li 23 (\%82.1) hastada mevcut iken, EAT'si olmayan 30 hastada (\%76.9) mevcuttu ( $p>0.05)$. Serum RF seviyeleri EAT'li hastalarda $176.5 \pm 201.7 \mathrm{IU} / \mathrm{ml}$ iken, EAT'siz hastalarda $114.1 \pm 144.8 \mathrm{IU} / \mathrm{ml}$ idi $(p>0.05)$. Pulmoner fibrozisi olan hastaların ortalama serum RF titreleri pulmoner fibrozisi olmayanlara göre anlamlı şekilde daha yüksek (sırasıyla $237.8 \pm 204.8 \mathrm{IU} / \mathrm{ml}$ ve $118.9 \pm 158.6 \mathrm{IU} / \mathrm{ml}$; $\mathrm{p}=0.036$ ) idi.

Sonuç: Romatoid artritli hastalarda EAT'lerin mortaliteyi ve morbiditeyi artırdığı bilinmektedir. Bu nedenle şiddetli hastalığı olan hastaların saptanmasına yardımcı olan belirleyiciler erken agresif tedaviye karar verilmesinde önemli rol oynamaktadır. Anti-CCP antikorları ile EAT arasındaki ilişkiyi araştıran çalışmalarda çelişkili sonuçlar bulunmuştur. Bu çalışmada CCP pozitifliği ile EAT varlığı arasında herhangi bir ilişki saptanmadı. Anti-CCP antikorları ile EAT arasındaki ilişkiyi değerlendirmek için daha fazla sayıda hasta içeren çalışmalara gereksinim olduğu düşüncesindeyiz.

Anahtar sözcükler: Anti-CCP antikorları; ekstra-artiküler tutulum; romatoid artrit; romatoid factor.

Received: January 21, 2010 Accepted: April 28, 2010

Correspondence: Özgür Ortancıl, M.D. Zonguldak Karaelmas Üniversitesi Tıp Fakültesi, Fiziksel Tıp ve Rehabilitasyon Anabilim Dalı, 67600 Zonguldak, Turkey. Tel: +90 372 - 2612465 e-mail: ozgurortancil@yahoo.com

(o2011 Turkish League Against Rheumatism. All rights reserved. 
Rheumatoid arthritis (RA) is a chronic inflammatory disease in which the peripheral joints are the primary sites of inflammation. It often leads to destruction in the joints involved. Extra-articular manifestations (EAM) occur, especially in patients with long-standing RA. ${ }^{[1]}$ The exact etiology of the disease has not been clearly defined to date. However, strong evidence suggests autoimmunity since several autoantibodies are associated with RA. Rheumatoid factor (RF), which is currently used in the diagnosis of RA, represents one of the classification criteria proposed by the American College of Rheumatology (ACR). ${ }^{[2]}$ In recent years, the assay for anti-cyclic citrullinated peptide (anti-CCP) antibodies, another diagnostic test for RA, has been developed. These serological markers are considered to be important in determining the prognosis of the disease. ${ }^{[3-9]}$ The presence of antiCCP antibodies and IgM RF are associated with a higher probability of radiological signs of joint damage. ${ }^{[10]}$ In a former study which investigated the relationship between anti-CCP antibodies and radiologic damage in Turkish patients with RA, it was found that there were no significant relations between anti-CCP antibodies and radiologic parameters. They also stated that further studies with larger groups were indicated to investigate this association. ${ }^{[1]}$ In studies on patients with active, severe extra-articular disease, high levels of RF were determined, suggesting that RF contributes to the pathogenesis of EAM. ${ }^{[12]}$ Studies investigating the association between CCP and EAM have had contradictory results. The aim of this study was to analyze the association of EAM (rheumatoid nodules, pulmonary nodules, pulmonary fibrosis, keratoconjunctivitis sicca) with anti-CCP antibodies.

\section{PATIENTS AND METHODS}

Sixty-seven patients (53 females, 14 males; mean age $57.4 \pm 13.5$ years; range 26 to 82 years) attending the Physical Medicine and Rehabilitation Clinic of Zonguldak Karaelmas University Hospital and fulfilling the American College of Rheumatology (ACR) criteria for $\mathrm{RA}^{[2]}$ were included in the study. The local ethics committee of Zonguldak Karaelmas University approved the study.

Blood samples were obtained from all the patients, and the age, gender, and disease duration along with the presence of EAM (rheumatoid nodules, pulmonary nodules, pulmonary fibrosis, keratoconjunctivitis sicca) were recorded.

Serum IgM RF concentrations were measured by automated immunonephelometry on the BN ProSpec
System (Dade Behring Inc., Newark, USA) by using a commercially available N Latex RF kit. (Dade Behring Inc., Newark, USA). The cut-off value was $15 \mathrm{IU} / \mathrm{ml}$. Second generation anti-CCP was analyzed by using a microplate ELISA kit (Euroimmun Medizinische Labordiagnostika AG, Luebeck, Germany) according to the manufacturer's instructions.

\section{Statistical analysis}

The statistical analyses were performed using SPSS (SPSS Inc., Chicago, Illinois, USA) for Windows 11.0 version software. Differences in means between the groups were analyzed with the Mann-Whitney U-test. Proportions were compared using the chi-square test. A binary multiple logistic regression model was created to evaluate the effects of RF and anti-CCP antibody positivity along with duration of disease for the development of EAM. While creating the model, duration of disease was divided into two categories through ROC analysis. The cut-off values of this group were found to be 5.5 years (sensitivity: 60.7\%, specificity: $66.6 \%$, likelihood ratio: 1.8$). P$ values less than 0.05 were considered statistically significant.

\section{RESULTS}

A total of 67 patients were involved in the study with 53 (79.1\%) being female and 14 (20.9\%) being male. They had a mean age of $57.4 \pm 13.5(26-82)$ years old, and the mean duration of disease was 10.1 \pm 11.7 (1-46) years. Extra-articular manifestations were present in $28(41.8 \%)$ of the patients [Keratoconjunctivitis sicca: three (4.5\%), subcutaneous nodules: 10 (14.9\%), pulmonary nodules: nine (13.4\%), pulmonary fibrosis: $12(17.9 \%)]$.

Anti-CCP antibodies were present in 34 (50.7\%) patients. Positivity of anti-CCP antibodies was found in 16 (57.1\%) patients with EAM compared to 18 (46.2\%) patients without EAM ( $p>0.05)$. Fifty-three (79.1\%) patients were positive for RF. Rheumatoid factor positivity was found in $23(82.1 \%)$ patients with EAM compared to 30 (76.9\%) patients without EAM $(\mathrm{p}>0.05)$. Fifteen patients with EAM (65.2\%) were both anti-CCP positive and RF positive compared to $18(60 \%)$ patients without EAM $(\mathrm{p}>0.05)$. Serum levels of RF were $176.5 \pm 201.7 \mathrm{IU} / \mathrm{ml}($ mean \pm SD) in the patients with EAM and $114.1 \pm 144.8 \mathrm{IU} / \mathrm{ml}$ in the patients without EAM ( $>0.05)$. Disease duration was significantly longer in the patients with EAM $(11.5 \pm 10.7$ years $)$ than in the patients without EAM $(9.2 \pm 12.4$ years; $p=0.046$; table 1$)$. The mean serum titers of RF were significantly higher in the patients 
Table 1. Clinical and laboratory findings of the patients

\begin{tabular}{|c|c|c|c|c|c|c|c|c|c|c|c|}
\hline & \multicolumn{5}{|c|}{ Patients with EAM } & \multicolumn{5}{|c|}{ Patients without EAM } & \multirow[b]{2}{*}{$p$} \\
\hline & $\mathrm{n}$ & $\%$ & Mean \pm SD & Median & (min.-max.) & $\mathrm{n}$ & $\%$ & Mean \pm SD & Median & (min.-max.) & \\
\hline Mean age (years) & & & $58.1 \pm 12.5$ & 56.5 & $(33-82)$ & & & $56.9 \pm 14.4$ & 60 & $(26-82)$ & $>0.05$ \\
\hline Disease duration (years) & & & $11.5 \pm 10.7$ & 8 & $(1-42)$ & & & $9.2 \pm 12.4$ & 3 & $(1-46)$ & 0.046 \\
\hline $\begin{array}{l}\text { Positivity of anti-CCP } \\
\text { antibodies }\end{array}$ & 16 & 57.1 & & & & 18 & 46.2 & & & & $>0.05$ \\
\hline RF positivity & 23 & 82.1 & & & & 30 & 76.9 & & & & $>0.05$ \\
\hline RF levels (IU/ml) & & & $176.5 \pm 201.7$ & 72 & $(0-604)$ & & & $114.1 \pm 144.8$ & 53 & $(0-604)$ & $>0.05$ \\
\hline
\end{tabular}

with pulmonary fibrosis than in the patients without pulmonary fibrosis $(237.8 \pm 204.8 \mathrm{IU} / \mathrm{ml}$ vs. $118.9 \pm 158.6$ $\mathrm{IU} / \mathrm{ml} \mathrm{p}=0.036$ ).

Positivity of anti-CCP antibodies was present in seven (70\%) patients with subcutaneous nodules compared to $27(47.3 \%)$ patients without subcutaneous nodules ( $\mathrm{p}>0.05)$; in one $(33.3 \%)$ patient with keratoconjunctivitis sicca compared to 33 (51.6\%) patients without keratoconjunctivitis sicca $(\mathrm{p}>0.05)$; in five $(55.5 \%)$ patients with pulmonary nodules compared to 29 (50\%) patients without pulmonary nodules ( $\mathrm{p}>0.05)$; and in seven (58.3\%) patients with pulmonary fibrosis compared to 27 (49.1\%) patients without pulmonary fibrosis ( $\mathrm{p}>0.05)$.

A logistic regression model was created to evaluate the effects of RF in conjunction with anti-CCP antibody positivity and duration of disease for the development of EAM. A binary multiple logistic regression analysis with duration of disease and positivity of RF and anti-CCP antibodies revealed that duration of disease longer than 5.5 years caused a 2.96-fold increase in the risk for EAM. Positivity of $\mathrm{RF}$ and anti-CCP antibodies were not associated with the development of EAM (table 2).

\section{DISCUSSION}

Rheumatoid arthritis is an inflammatory and autoimmune disease that is responsible for joint destruction. Extra-articular manifestations may occur depending on the severity. Inadequate treatment of RA results in a significantly reduced quality of life, increased morbidity, and mortality in the long-term. ${ }^{[13]}$ Thus, early diagnosis and proper treatment is highly crucial for the prognosis of RA. A decision can be made for early aggressive treatment using the markers that help determine patients with severe disease. Clinical factors such as age of onset, number of joints involved, persistently elevated C-reactive protein, and presence of RF are well-recognized predictors of severe disease. ${ }^{[14,15]}$ Moreover, anti-CCP antibodies, which predict the development of RA in early arthritis, have been associated with severe disease. ${ }^{[16]}$

Many autoantibodies against various citrullinated peptides occur in RA. These antibodies can be detected by serological tests using synthetic citrullinated substrates. ${ }^{[17]}$ First generation ELISAs (anti-CCP1) gave a specificity for RA of about $85 \%$ with a sensitivity of $65 \%$ to $70 \% \cdot{ }^{[13]}$ A second generation anti-CCP ELISA (anti-CCP2), with higher sensitivity and specificity due to the optimalization of the substrate, was developed to improve on anti-CCP1. ${ }^{[18]}$ Use of these cyclic citrullinated peptides has improved the specificity to between $96 \%$ and $98 \%$ without changing the sensitivity. ${ }^{[19]}$ At present, the anti CCP2 ELISA is the most widely used test in international studies. ${ }^{[20]}$ A third generation test (anti-CCP3) is commercially available. Citrullinated vimentin has been described

\begin{tabular}{|c|c|c|c|c|}
\hline & \multirow[t]{2}{*}{ Odds ratio } & \multicolumn{2}{|c|}{ 95\% CI for Odds ratio } & \multirow[b]{2}{*}{$p$} \\
\hline & & Lower & Upper & \\
\hline Disease duration $>5.5$ years & 2.960 & 1.067 & 8.212 & 0.037 \\
\hline Positivity of anti-CCP antibodies & 0.678 & 0.226 & 2.035 & 0.488 \\
\hline Rheumatoid factor positivity & 0.886 & 0.223 & 3.514 & 0.863 \\
\hline
\end{tabular}


as a relevant autoantigen expressed in synovial tissue. An ELISA based on mutated citrullinated vimentin (MCV) has been available for the diagnosis of RA. ${ }^{[13]}$ The anti CCP3 test seems to be as sensitive as antiCCP2 and more sensitive than MCV. ${ }^{[20]}$

Studies that investigate the association between anti-CCP antibodies and EAM have reported contradictory results. De Rycke et al. ${ }^{[1]}$ found no relationship between anti-CCP antibodies and EAM. On the other hand, in a study by Kim et al. ${ }^{[21]}$ from Korea, longer disease duration, smoking history, and positive anti-CCP antibodies were reported to have a significant role in the development of EAM. Similarly, in a case-controlled study in Sweden, a significantly larger proportion of patients with severe EAM had anti-CCP antibodies $(p=0.03)$ than the patients without EAM. However, the titers of the two groups did not differ significantly. ${ }^{[12]}$ In a study from Greece, it was suggested that RA patients with high anti-CCP2 levels $(>100 \mathrm{IU} / \mathrm{ml})$ were more likely to have EAM (serositis and pulmonary fibrosis) than RA patients without high serum CCP2 levels. ${ }^{[22]}$ In a previous study on Turkish patients with RA, antiCCP antibodies did not show any association with EAM. $^{[23]}$ Similarly, in our study, no relationships were found between antibodies against citrullinated peptides and the presence of EAM. Vencovský et al. ${ }^{[24]}$ demonstrated that the combined use of RF and anti-CCP antibodies is highly predictive for more progressive disease. We found no difference between the positivity of anti-CCP antibodies and RF in patients either with or without EAM.

In this study, the relationship between RF positivity and EAM was also evaluated. In contrast to other studies, ${ }^{[1,25]}$ we could not find any relationship between RF positivity and EAM. Nevertheless, RF levels were significantly higher in the patients with lung fibrosis. We concluded that our failure to find a significant relationship between RF positivity and EAM might be associated with the small sample size.

The prevalence of EAM in RA varies significantly depending on the ethnic populations or geographic areas. Another factor is the lack of definite inclusion criteria for EAM used in each study. For example, in the Caucasian population in the Great Britain and North America, ${ }^{[26,27]}$ EAM was significantly prevalent compared with East Asian and African populations. ${ }^{[28-29]}$ In this study, the rate of EAM was $41.8 \%$. A previous study investigating EAM in the Turkish population reported a rate of $38.4 \%$ for EAM presence. ${ }^{[30]}$ The prevalence of EAM in Turkey seems to be higher than in East Asia and Africa but lower than in the Great Britain and North America.

In this study, disease duration was significantly longer in the patients with EAM than in the patients without EAM. Turesson et al. ${ }^{[31]}$ have reported severe EAM in both patients recently diagnosed with RA and those with long-standing disease. Kim et al. ${ }^{[21]}$ concluded that disease duration was closely associated with the development of EAM. According to Korkmaz et al. ${ }^{[23]}$ EAM was 2.6 times more common in long-standing RA compared to an early RA group.

In conclusion, as EAM increases morbidity and mortality in patients with RA, markers that can help identify patients with severe disease may be used in the decision-making process for early institution of aggressive treatment. Studies investigating the association between anti-CCP antibodies and EAM have reported conflicting results. In this study, we could not find any association between antibodies against citrullinated peptides and the presence of EAM. Further studies with a larger sample size are necessary to evaluate the association of EAM and antiCCP antibodies.

\section{Declaration of conflicting interests}

The authors declared no conflicts of interest with respect to the authorship and/or publication of this article.

\section{Funding}

The authors received no financial support for the research and/or authorship of this article.

\section{REFERENCES}

1. De Rycke L, Peene I, Hoffman IE, Kruithof E, Union A, Meheus L, et al. Rheumatoid factor and anticitrullinated protein antibodies in rheumatoid arthritis: diagnostic value, associations with radiological progression rate, and extra-articular manifestations. Ann Rheum Dis 2004;63:1587-93.

2. Arnett FC, Edworthy SM, Bloch DA, McShane DJ, Fries JF, Cooper NS, et al. The American Rheumatism Association 1987 revised criteria for the classification of rheumatoid arthritis. Arthritis Rheum 1988;31:315-24.

3. van Jaarsveld $\mathrm{CH}$, ter Borg EJ, Jacobs JW, Schellekens GA, Gmelig-Meyling FH, van Booma-Frankfort C, et al. The prognostic value of the antiperinuclear factor, anticitrullinated peptide antibodies and rheumatoid factor in early rheumatoid arthritis. Clin Exp Rheumatol 1999;17:689-97. 
4. Schellekens GA, Visser H, de Jong BA, van den Hoogen FH, Hazes JM, Breedveld FC, et al. The diagnostic properties of rheumatoid arthritis antibodies recognizing a cyclic citrullinated peptide. Arthritis Rheum 2000;43:155-63.

5. Kroot EJ, de Jong BA, van Leeuwen MA, Swinkels $H$, van den Hoogen $\mathrm{FH}$, van't Hof $\mathrm{M}$, et al. The prognostic value of anti-cyclic citrullinated peptide antibody in patients with recent-onset rheumatoid arthritis. Arthritis Rheum 2000;43:1831-5.

6. van Zeben D, Hazes JM, Zwinderman AH, Cats A, van der Voort EA, Breedveld FC. Clinical significance of rheumatoid factors in early rheumatoid arthritis: results of a follow up study. Ann Rheum Dis 1992;51:1029-35.

7. Jónsson T, Valdimarsson $\mathrm{H}$. Clinical significance of rheumatoid factor isotypes in seropositive arthritis. Rheumatol Int 1992;12:111-3.

8. Houssien DA, Jonsson T, Davies E, Scott DL. Clinical significance of IgA rheumatoid factor subclasses in rheumatoid arthritis. J Rheumatol 1997;24:2119-22.

9. Houssien DA, Jónsson T, Davies E, Scott DL. Rheumatoid factor isotypes, disease activity and the outcome of rheumatoid arthritis: comparative effects of different antigens. Scand J Rheumatol 1998;27:46-53.

10. Bas S, Genevay S, Meyer O, Gabay C. Anti-cyclic citrullinated peptide antibodies, $\operatorname{IgM}$ and $\operatorname{IgA}$ rheumatoid factors in the diagnosis and prognosis of rheumatoid arthritis. Rheumatology (Oxford) 2003;42:677-80.

11. Dündar U, Evcik D, Çakır T, Aktepe O, Altındış M, Kavuncu V. Romatod artritli hastalarda anti-CCP antikorlarının hastalık aktivitesi ve radyolojik hasar ile ilișkisi. Turk J Rheumatol 2005;20:9-14.

12. Turesson C, Jacobsson LT, Sturfelt G, Matteson EL, Mathsson L, Rönnelid J. Rheumatoid factor and antibodies to cyclic citrullinated peptides are associated with severe extra-articular manifestations in rheumatoid arthritis. Ann Rheum Dis 2007;66:59-64.

13. Egerer K, Feist E, Burmester GR. The serological diagnosis of rheumatoid arthritis: antibodies to citrullinated antigens. Dtsch Arztebl Int 2009;106:159-63.

14. Combe B, Eliaou JF, Daurès JP, Meyer O, Clot J, Sany J. Prognostic factors in rheumatoid arthritis. Comparative study of two subsets of patients according to severity of articular damage. Br J Rheumatol 1995;34:529-34.

15. van der Heijde DM, van Riel PL, van Leeuwen MA, van 't Hof MA, van Rijswijk MH, van de Putte LB. Prognostic factors for radiographic damage and physical disability in early rheumatoid arthritis. A prospective follow-up study of 147 patients. Br J Rheumatol 1992;31:519-25.

16. ForslindK, Ahlmén M,EberhardtK,HafströmI,Svensson B; BARFOT Study Group. Prediction of radiological outcome in early rheumatoid arthritis in clinical practice: role of antibodies to citrullinated peptides (anti-CCP). Ann Rheum Dis 2004;63:1090-5.
17. Vincent C, Nogueira L, Sebbag M, Chapuy-Regaud S, Arnaud M, Letourneur O, et al. Detection of antibodies to deiminated recombinant rat filaggrin by enzymelinked immunosorbent assay: a highly effective test for the diagnosis of rheumatoid arthritis. Arthritis Rheum 2002;46:2051-8.

18. Suzuki K, Sawada T, Murakami A, Matsui T, Tohma S, Nakazono K, et al. High diagnostic performance of ELISA detection of antibodies to citrullinated antigens in rheumatoid arthritis. Scand J Rheumatol 2003;32:197-204.

19. van Venrooij WJ, Zendman AJ, Pruijn GJ. Autoantibodies to citrullinated antigens in (early) rheumatoid arthritis. Autoimmun Rev 2006;6:37-41.

20. Goëb V, Jouen F, Gilbert D, Le Loët X, Tron F, Vittecoq O. Diagnostic and prognostic usefulness of antibodies to citrullinated peptides. Joint Bone Spine 2009;76:343-9.

21. Kim SK, Park SH, Shin IH, Choe JY. Anti-cyclic citrullinated peptide antibody, smoking, alcohol consumption, and disease duration as risk factors for extraarticular manifestations in Korean patients with rheumatoid arthritis. J Rheumatol 2008;35:995-1001.

22. Alexiou I, Germenis A, Koutroumpas A, Kontogianni A, Theodoridou K, Sakkas LI. Anti-cyclic citrullinated peptide-2 (CCP2) autoantibodies and extra-articular manifestations in Greek patients with rheumatoid arthritis. Clin Rheumatol 2008;27:511-3.

23. Korkmaz C, Us T, Kaşifoğlu T, Akgün Y. Anti-cyclic citrullinated peptide (CCP) antibodies in patients with long-standing rheumatoid arthritis and their relationship with extra-articular manifestations. Clin Biochem 2006;39:961-5.

24. Vencovský J, Machácek S, Sedová L, Kafková J, Gatterová J, Pesáková V, et al. Autoantibodies can be prognostic markers of an erosive disease in early rheumatoid arthritis. Ann Rheum Dis 2003;62:427-30.

25. Bas S, Perneger TV, Mikhnevitch E, Seitz M, Tiercy JM, Roux-Lombard P, et al. Association of rheumatoid factors and anti-filaggrin antibodies with severity of erosions in rheumatoid arthritis. Rheumatology (Oxford) 2000;39:1082-8.

26. Gordon DA, Stein JL, Broder I. The extra-articular features of rheumatoid arthritis. A systematic analysis of 127 cases. Am J Med 1973;54:445-52.

27. Turesson C, O'Fallon WM, Crowson CS, Gabriel SE, Matteson EL. Extra-articular disease manifestations in rheumatoid arthritis: incidence trends and risk factors over 46 years. Ann Rheum Dis 2003;62:722-7.

28. Turesson C, Jacobsson L, Bergström U, Truedsson L, Sturfelt G. Predictors of extra-articular manifestations in rheumatoid arthritis. Scand J Rheumatol 2000;29:358-64. 
29. Voskuyl AE, Zwinderman AH, Westedt ML, Vandenbroucke JP, Breedveld FC, Hazes JM. Factors associated with the development of vasculitis in rheumatoid arthritis: results of a case-control study. Ann Rheum Dis 1996;55:190-2.

30. Calgüneri $M$, Ureten $K$, Akif Oztürk $M$, Onat AM,
Ertenli I, Kiraz S, et al. Extra-articular manifestations of rheumatoid arthritis: results of a university hospital of 526 patients in Turkey. Clin Exp Rheumatol 2006;24:305-8.

31. Turesson C, Jacobsson L, Bergström U. Extra-articular rheumatoid arthritis: prevalence and mortality. Rheumatology (Oxford) 1999;38:668-74. 